\title{
Changing contribution of peak velocity events to annual velocities following a multi-decadal slowdown at White Glacier
}

\author{
Laura I. THOMSON, ${ }^{1}$ Luke COPLAND ${ }^{2}$ \\ ${ }^{1}$ Department of Earth Sciences, Simon Fraser University, Burnaby, British Columbia V5A 1S6, Canada \\ E-mail: Ithomson@sfu.ca \\ ${ }^{2}$ Department of Geography, Environment and Geomatics, University of Ottawa, Ottawa, Ontario K1N 6N5, Canada
}

\begin{abstract}
As the focus of intensive glaciological studies in the 1960-70s, White Glacier on Axel Heiberg Island, Canada, has played an important role in understanding the dynamics of mostly-cold polythermal glaciers in the high Arctic. In this study, we examine the magnitude, duration and timing of peak velocity events in the summers of 2013-15 using continuous dual-frequency GPS observations, and compare them with similar measurements made in 1968. Summer speed-up events in 1968 and 2014, in which ice velocities reached $200 \%$ above winter values, were found to occur in conjunction with formation and drainage of an ice-marginal lake. Despite thinning of the glacier by $>20 \mathrm{~m}$ and a decrease in annual surface velocities of $15-35 \%$ since the 1960 s, the relative magnitude and duration of these peak events has increased, particularly at lower elevations, in comparison with the observations at the same locations many decades ago. Given the long-term slowdown of the glacier, the relative contribution of summer displacement to the net annual motion has therefore increased significantly, with summer motion over the span of $<\mathbf{2}$ months now accounting for nearly half of the total annual displacement.
\end{abstract}

KEYWORDS: Arctic glaciology, ice dynamics, ice velocity

\section{INTRODUCTION}

The long-term evolution of glacier velocities, which control the delivery of ice to warm, low elevation regions, is an important component of the future stability of ice masses in a warming climate. For a glacier in steady state, mass transfer through a cross section will equal the cumulative massbalance conditions upstream. The transition to increasingly negative mass-balance conditions will reduce mass flux and, therefore, ice velocity. The mechanism for this deceleration can be linked to reduced ice deformation rates according to Glen's flow law (Glen, 1955) as a result of thinning. Evidence of glacier deceleration in response to persistent negative mass-balance conditions has been shown for several land-terminating glaciers across the planet (Heid and Kääb, 2012; Schaffer and others, 2017; Thomson and others, 2017), and in occasional cases glacier acceleration has been observed when positive mass-balance conditions increase ice thickness (Nolan and others, 1995; Anderson and others, 2014). However, there is limited knowledge about changes to the nature of peak velocity events, defined here as speed-up events occurring over the period of days to weeks during the summer melt season. As the only glacier in the Canadian Arctic with high-temporal-resolution measurements of velocities dating back to the 1960s (Iken, 1974), White Glacier provides a unique opportunity to assess multi-decadal changes to peak velocity events.

White Glacier was the focus of numerous glaciological studies based out of the McGill Arctic Research Station in the Expedition Fiord region of Axel Heiberg Island during the 1960s and 1970s (Müller, 1963; Adams, 2007). Observations of annual and seasonal glacier velocities were initiated in 1960 (Müller and Iken, 1973) and continued at temporal resolutions spanning from $3 \mathrm{~h}$ to 10 days by Almut Iken during the summers of 1968-71 (Iken, 1974). Earlier observations of ice velocities for high-Arctic glaciers showed evidence of a correlation between ablation and ice motion (Battle, 1951; Friese-Greene and Pert, 1965), which motivated higher frequency observations of ice motion at White Glacier in combination with measurements of surface melt and water pressure in moulins (Iken, 1974). These observations indicated that, although White Glacier is a mostly-cold polythermal glacier, a temperate-ice zone at the glacier bed enabled sliding to occur in response to increased basal water pressure (Iken, 1974). Contemporary observations at other high-latitude glaciers indicate that peak velocity events are closely linked to the input of surface meltwater, the structure of the subglacial hydrological system efficiency at which water leaves the subglacial system (Bartholomaus and others, 2008; Cuffey and Paterson, 2010; Sundal and others, 2011). Furthermore, these processes appear to be effective not only in temperate glaciers, but also in mostly-cold polythermal glaciers (Bingham and others, 2003, 2006; Copland and others, 2003; Hambrey and others, 2005).

A recent assessment of annual and seasonal ice motion at White Glacier through comparison of temporally-coarse observations conducted between 1960-70 (Müller and Iken, 1973) and 2012-16 (Thomson and Copland, 2017) suggests an increase in the contribution of summer displacement to annual displacement over the past half-century. This study aims to determine the role of peak velocity events in annual motion via the comparison of high-resolution velocity measurements available for 1968 (Iken, 1974) and dual-frequency GPS data from 2013 to 2015. Specifically, we quantify changes to the magnitude and duration of peak velocity events at White Glacier and discuss the potential processes responsible for the increased contribution of these events to the annual motion.

Comparing velocity data between specific years must be conducted with consideration for the potential impacts of intraannual variability in meteorological conditions. In 
Table 1. Comparison of Eureka temperatures in 1968 and the years of recent White Glacier observations (2013-15)

\begin{tabular}{lcccc}
\hline Year & $\begin{array}{l}s_{\mathrm{t}} \\
\text { days }\end{array}$ & $\begin{array}{l}\text { PDD } \\
{ }^{\circ} \mathrm{C}\end{array}$ & $\begin{array}{l}\text { Mean dT } \\
{ }^{\circ} \mathrm{C}\end{array}$ & $\begin{array}{l}\text { Max dT } \\
{ }^{\circ} \mathrm{C}\end{array}$ \\
\hline 1968 & 89 & 387.7 & - & - \\
- & - & - & - & - \\
2013 & 63 & 226.8 & -2.3 & 9.7 \\
2014 & 85 & 378.7 & 0.6 & 6.8 \\
2015 & 93 & 565.1 & 1.1 & 6.6
\end{tabular}

The duration of the summer period, $s_{\mathrm{t}}$, is defined as the number of days for which the 5-day running mean $>0{ }^{\circ} \mathrm{C}$ (Müller and Iken, 1973). Positive degree days, PDD, refer to the cumulative of daily mean temperatures for all days $>0{ }^{\circ} \mathrm{C}$. Mean dT and max dT provide the average and maximum of the residual between daily mean temperatures in 1968 and 2014 during summer conditions.

addition, while sub-daily GPS position measurements were collected for 2013-15, velocities for 1968 were calculated from observations collected over periods of 1-10 days. To address intraannual variability, an initial experiment in temporal down-sampling of the GPS data are presented in the Data re-sampling section using data from 1968 and 2014, for which the summer climate conditions are most similar (Table 1, Fig. 2). Thereafter, GPS-derived velocities from 2013 to 2015 down-sampled to a 5-day window are used for comparison with peak velocity events in 1968 .

\section{SITE DESCRIPTION}

White Glacier $\left(79.45^{\circ} \mathrm{N}, 90.67^{\circ} \mathrm{W}\right)$ is a $14 \mathrm{~km}$ long alpine glacier extending from 80 to $1782 \mathrm{~m}$ a.s.l. in the Expedition Fiord region of Axel Heiberg Island, Nunavut. The mean annual temperature of the region is $\sim-20^{\circ} \mathrm{C}$ and mean precipitation at the highest elevations is $\sim 370 \mathrm{~mm} \mathrm{a}^{-1}$, based upon a 41-year snow pit record of annual accumulation on Müller Ice Cap (Cogley and others, 1996). Since the onset of mass-balance observations in 1960, the mean decadal ELA has risen from $1000 \mathrm{~m}$ a.s.l. during the 1960 s to 1270 $\mathrm{m}$ a.s.l. between 2006 and 2015, and the mean decadal accumulation area ratio has decreased from 0.61 to 0.32 over the same timeframe (Thomson and others, 2017). White Glacier is one of 37 official reference glaciers within the Global Terrestrial Network for Glaciers through the United Nations Framework Convention on Climate Change, managed in part by the World Glacier Monitoring Service where the mass-balance measurements are submitted annually (WGMS, 2015). Englacial temperature measurements conducted between 1974 and 1981 in boreholes drilled to the glacier bed revealed a mostly-cold polythermal structure $\left(<10^{\circ} \mathrm{C}\right.$ for the majority of ice volume), where temperatures only approach pressure melting point at a $6.4 \mathrm{~km}$ long and $0.5 \mathrm{~km}$ wide portion of the glacier bed in the lower ablation area (Blatter, 1987).

Summer velocity observations in 1968 were made at three cross-sectional profiles: Moraine $(870 \mathrm{~m}$ a.s.l.), Wind $(580 \mathrm{~m}$ a.s.I.), and Anniversary (370 $\mathrm{m}$ a.s.I.) profile and a fourth site the Lower Ice Station (210 $\mathrm{m}$ a.s.I.), all of which are located in the ablation area (Fig. 1). This study focuses on Moraine, Wind and Anniversary profiles, which are hereafter referred to as the upper, middle and lower profiles, respectively. Throughout the 1960s, mean annual surface velocities $\left(v_{\mathrm{a}}\right)$ along the glacier centreline at the upper, middle and lower

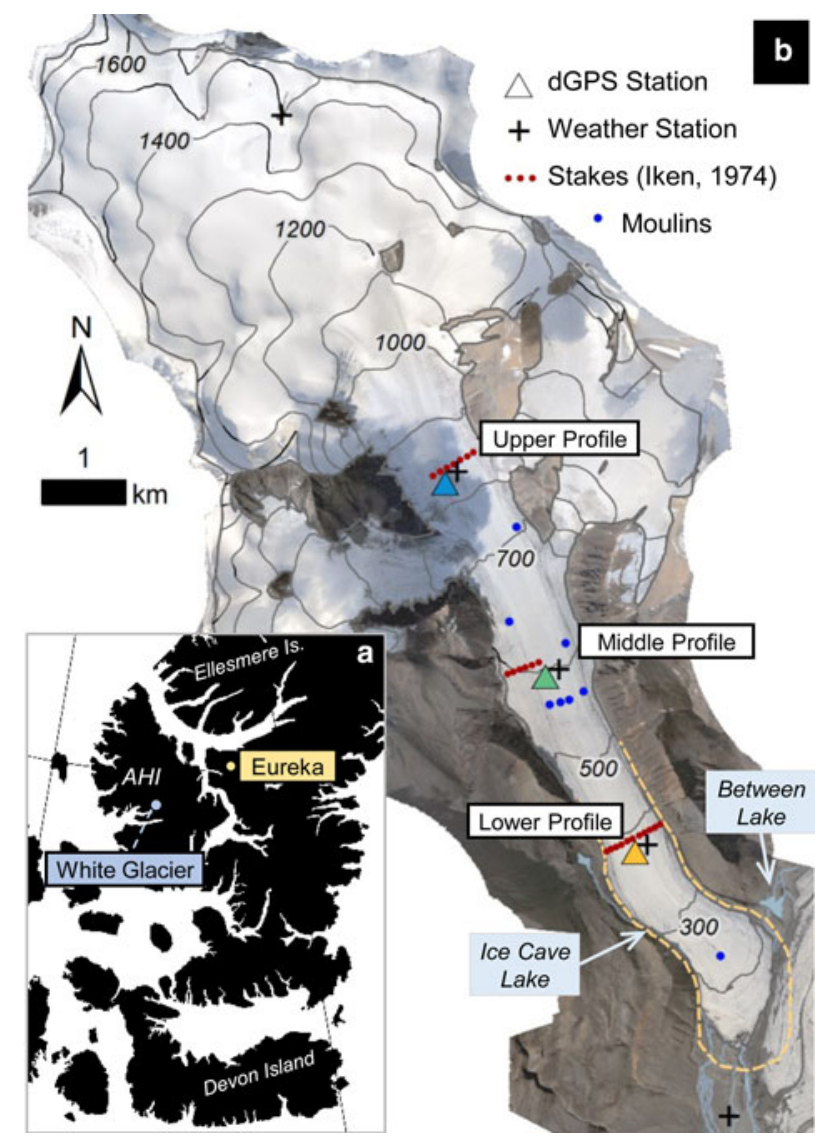

Fig. 1. (a) Location of White Glacier on Axel Heiberg Island (AHI), and the Eureka weather station on Ellesmere Island. (b) Orthoimage of White Glacier (Thomson and Copland, 2016) indicating the cross-profiles where surface velocities were observed during the 1960s and 2013-15, and the location of moulins known to be seasonally active in both 1968 and since 2013. The colours of the dual-frequency GPS station triangles correlate with colours of the velocity plots in Figures 3, 4.

stations were $10.2,10.5$ and $8.81 \mathrm{~cm} \mathrm{~d}^{-1}$, respectively (Müller and Iken, 1973). Repeat observations of annual surface velocities over the period $2012-16$ by Thomson and Copland (2017) found no statistically significant change in velocity at the upper station, while surface velocities decreased at the middle station by $31 \%(10.53-7.31 \mathrm{~cm}$ $\left.\mathrm{d}^{-1}\right)$ and at the lower station by $38 \%\left(8.81-5.41 \mathrm{~cm} \mathrm{~d}^{-1}\right)$. In accordance with Iken (1974), mean summer velocities $\left(v_{\mathrm{s}}\right)$ were calculated from the displacement over the temperature-defined summer period $\left(s_{t}\right)$, defined as the span of time in which the 5-day mean temperature is above $0^{\circ} \mathrm{C}$. Similar to $v_{\mathrm{a}}, v_{\mathrm{s}}$ decreased at the middle and lower stations by 12 and $35 \%$, respectively, while a $12 \%$ increase in summer motion was observed at the upper station. Comparison of topographic maps from 1960 (Haumann and Honegger, 1964) and 2014 (Thomson and Copland, 2016) indicate ice thinning of $23 \mathrm{~m}, 19.5 \mathrm{~m}$ and $19 \mathrm{~m}$ at the upper, middle and lower profiles, respectively. Mean ablation over the past 10 years (2005-15) is higher than annual ablation in the 1960 s by $287 \%$ (increasing from $305 \mathrm{~mm}$ w.e. to 876 $\mathrm{mm}$ w.e.) at the upper profile, $169 \%$ (863 $\mathrm{mm}$ w.e. to $1455 \mathrm{~mm}$ w.e.) at the middle profile and $143 \%$ (1286 mm w.e. to $1843 \mathrm{~mm}$ w.e.) at the lower profile. The marked increase in ablation at the upper station, relative to the middle and lower stations, could be due to shading from steep valley walls at lower elevations, and potentially to 


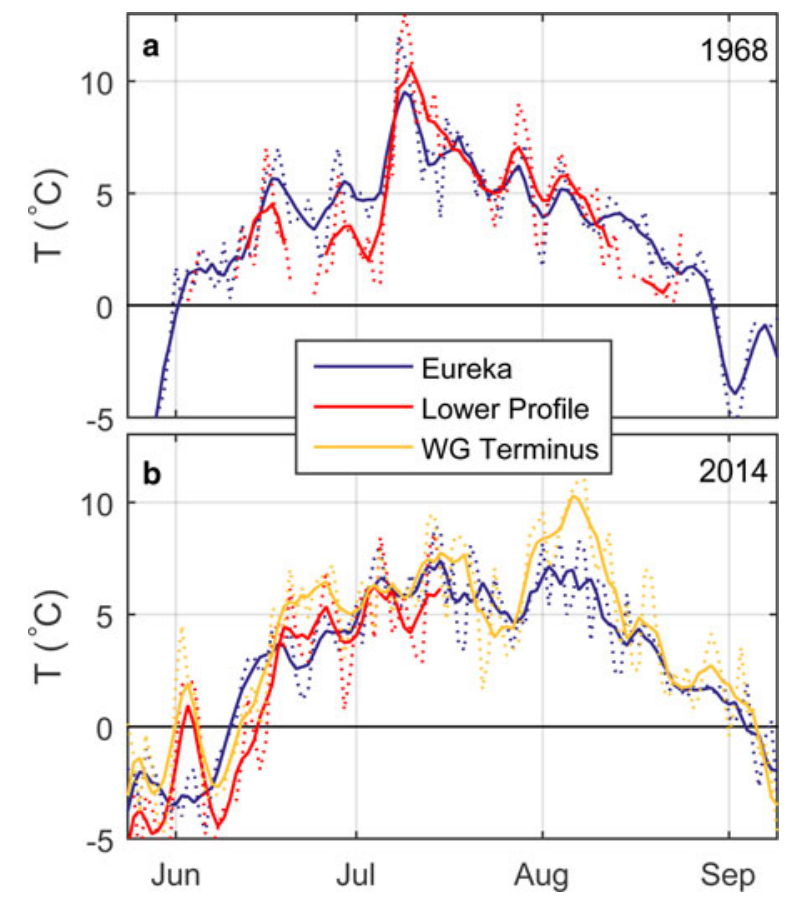

Fig. 2. Comparison of 1968 and 2014 daily (dotted) and 5-day mean (solid) surface air temperatures recorded at Eureka weather station, at the lower profile, and on the glacier end moraine (WG Terminus).

the strong temperature inversions that occur at high elevations on White Glacier through fall, winter and spring.

\section{METHODS}

\section{Velocity observations}

In 1968 surface velocities were calculated from repeat measurements of glacier stake positions (see Fig. 1 for stake locations) using a Wild T-2 theodolite and survey baselines first established in 1960 along the glacier margins (Iken, 1974). Field surveys were initiated on 30 April 1968, with the intention of conducting observations at all stations as simultaneously as field conditions would allow. Early in the 1968 field season, however, it became apparent that velocity fluctuations at the lower profile were particularly evident. Consequently, the sampling frequency was adjusted to 2-3 days at the lower profile, while the upper and middle profiles were surveyed following every second set of observations at the lower profile. Stake velocities were derived from both angular velocities collected by theodolite measurements at survey locations along the ice margin, which provide the displacement magnitude but not direction, and from stake positions on successive dates that provide both magnitude and direction (Iken, 1974). Measurement errors are not noted explicitly in Iken (1974), but Thomson and Copland (2017) calculated the discrepancy between the two methods of velocity calculation to be $\sim 0.2 \mathrm{~cm} \mathrm{~d}^{-1}$.

Contemporary velocity observations are based on position data from three Trimble R7 dual-frequency GPS units that were installed at the middle profile in April 2012, at the upper profile in April 2013 and at the lower profile in July 2013. The units were powered by $12 \mathrm{~V}$ batteries that are charged in the summer months by a solar panel mounted on a $4.5 \mathrm{~m}$ steel pole drilled $\sim 3.5 \mathrm{~m}$ into the ice each spring field season (mid-April to mid-May). With the exception of $1 \mathrm{~h}$ daily positions collected at the middle profile during 2012, all stations were programmed to collect position data every $15 \mathrm{~s}$ continuously through the year. Due to loss of solar power, once polar night begins, observations generally stop in mid-fall and are manually restarted in April when the stations are downloaded and re-installed. Post-processing of the GPS data are described in detail in Thomson and Copland (2017) and is based on the Precise Point Positioning (PPP) tool provided by Natural Resources Canada (http://webapp.geod.nrcan.gc.ca/geod/tools-outils/ ppp.php), which provides 3-D (Easting, Northing, Elevation) accuracies of $\sim \pm 2 \mathrm{~cm}$ for an observation period of $1 \mathrm{~h}$. The calculation of daily velocity from GPS position measurements mimics the approach of Bartholomaus and others (2008), in which easting and northing data are subject to coordinate rotation, enabling the down-glacier component of ice displacement to be assessed. Daily velocities are derived from the slope of a linear fit through the GPS observations spanning 1 day, centred on noon local time. The mean $R^{2}$ of the linear fit for which the velocity calculations were based is 0.84 and $>50 \%$ of $R^{2}$ values exceed 0.9 . The mean RMSE of the polynomial fit data are $0.013 \mathrm{~m} \mathrm{~d}^{-1}$, which is used as an approximation of the error for the contemporary velocity calculations. For comparison with 1968 data in which velocities are derived from repeat stake measurements spanning multiple days (Iken, 1974), the displacement between daily mean coordinate positions is used, as described in the Data re-sampling section.

\section{Meteorological data}

While weather observations were an important component to many studies at White Glacier during the 1960s and 1970s, temperature records spanning the 1968 observations are only available intermittently for the lower profile. It is, therefore, necessary to consider climate data from the Environment Canada Eureka weather station $\sim 100 \mathrm{~km}$ east of White Glacier as a proxy (location in Fig. 1). Contemporary temperature data for White Glacier are available from three shielded Onset ${ }^{\circledR}$ HOBO U23 Pro v2 Temperature/Relative Humidity data loggers mounted on poles $1-3 \mathrm{~m}$ above the ice at the three profiles, although it should be noted that temperatures are not available for the upper and lower stations from 9 July 2014 to 20 April 2015 due to battery failures at both stations. However, continuous temperature data are available for the middle profile and from two off-ice automatic weather stations located on a nunatak in the accumulation area (1511 $\mathrm{m}$ a.s.l.) and on the glacier end moraine (35 $\mathrm{m}$ a. s.l.). Together, the temperature data from these stations are used to model temperatures where data gaps exist using known station elevations and the daily mean temperaturelapse rates. Comparison between temperatures at Eureka and: (1) the lower profile in 1968 and (2) the lower profile and on the glacier end moraine in 2014, demonstrate that Eureka provides a reasonable proxy for climate conditions in the Expedition Fiord region during summer months (Fig. 2). Differencing temperature data from Eureka and the lower profile on White Glacier during days with positive temperatures, results in a mean residual of $0.5^{\circ} \mathrm{C}$ in 1968 and $-0.1^{\circ} \mathrm{C}$ in 2014 . In the following analysis, velocity data from 2014 is compared with 1968 data because this is the year most similar to the 1968 summer conditions, both in terms of $s_{t}$ and the magnitude of positive degree days (Table 1). 


\begin{abstract}
Ablation
Ablation measurements available from the 55-year massbalance record provide the cumulative annual melt at each of the three cross-profiles from 1960 to 2015. In 1968 the progression and variability of ablation through the summer period was monitored at intervals of 4-22 days at the upper and middle profiles and 1-9 days at the lower profile. Since 2012, ultrasonic depth sounder measurements of ablation have been logged at the middle station, which provides a measure of melt variability and amount through the summer months in conjunction with recorded surface air temperatures.
\end{abstract}

\section{RESULTS}

\section{Observed summer velocities and climate conditions: 1968}

Records from Iken (1974) of velocity fluctuations observed at the upper, middle and lower profiles in 1968, mean ablation at a series of stakes at each profile and the formation and drainage of an ice-marginal lake (Ice cave Lake) are illustrated in Figure 3 and summarized with contemporary velocity observations in Table 2. As described in Iken (1974), the onset of melt conditions in 1968 began in early May and was followed by a mid-May storm that left the glacier snowcovered until 31 May when significant melt started and marginal streams were observed as high as the middle profile. During mid-May ( 11-23) surface velocities were at their minimum, $\sim 90-95 \%$ of the measured winter velocity. A period of cool weather extended from 6-11 June followed by strong winds. On 11 June, velocities at the lower profile underwent a rapid increase and exceeded mid-May velocities by $45 \%$ from 15 to 18 June and $55 \%$ from 18 to 21 June. At the middle and upper profiles, zero to minimal increases in velocity was observed from late-May to mid-June. Light snowfall during 18-19 June limited further ablation and cool temperatures persisted until 27 June.

On 30 June high elevation supraglacial streams were established and peak temperatures occurred during 8-10 July, which led to high ablation rates and a peak in velocities at the lower profile of $25.6 \mathrm{~cm} \mathrm{~d}^{-1}$, close to $200 \%$ above the spring velocity minimum (Fig. 3). The majority of supraglacial streams end in moulins, and turbid water was observed leaving the glacier through marginal streams near Ice cave Lake and Between Lake (see Fig. 1). Maximum velocities at the middle profile of $13.8 \mathrm{~cm} \mathrm{~d}^{-1}$ occurred from 15 to 19 July $\sim 1$ week after the lower profile peak and at the upper profile peak velocities $\left(13.9 \mathrm{~cm} \mathrm{~d}^{-1}\right)$ lagged only 1 day behind the middle profile, with peak velocities from 16 to 20 July. Ice cave Lake, a marginal lake associated with an ice cave $700 \mathrm{~m}$ downstream of the lower profile, was observed to form from 30 May to 4 June, after which lake levels dropped at an increasing rate until it was fully drained on 21 June. Studies by Maag (1969) indicate that the maximum volume of water in the lake was $\sim 19000 \mathrm{~m}^{3}$, and that the subglacial channels that drain the lake exit the western glacier margin $\sim 400 \mathrm{~m}$ downstream of the ice cave.

\section{Observed summer velocities and climate conditions: 2013-15}

Daily GPS-derived summer velocities and corresponding temperatures observed at the middle profile are presented
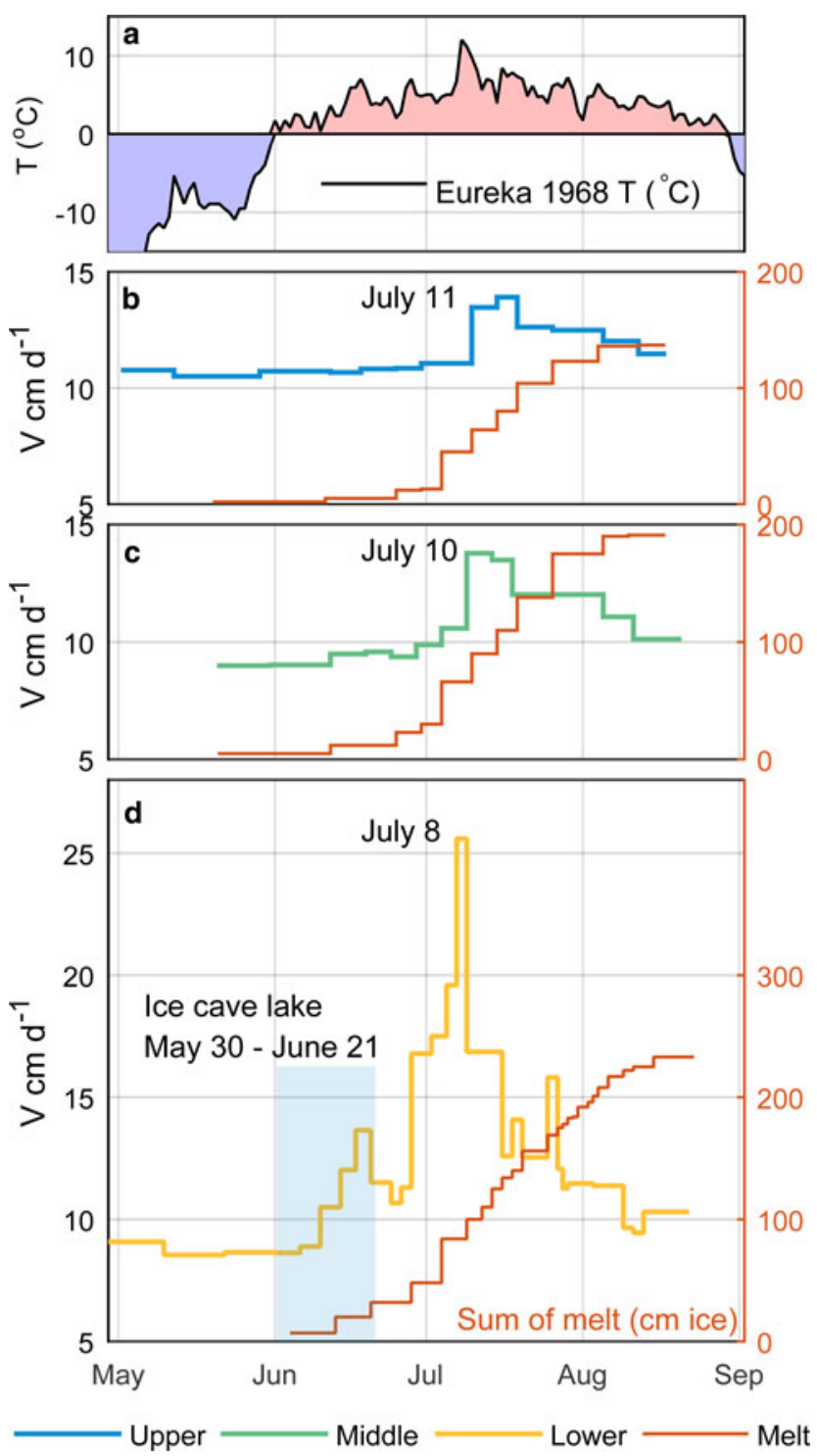

Fig. 3. (a) Climate data from Eureka weather station, summer of 1968. Velocity data based on Iken (1974) for the (b) upper, (c) middle and (d) lower profiles is plotted along the left-hand $y$-axis and the cumulative melt (in $\mathrm{cm}$ ) observed at each profile is plotted on the right. The light-blue region in (d) indicates the period of time spanning the formation and drainage of an ice-marginal lake $1 \mathrm{~km}$ down-glacier of lower profile.

in Figure 4. The variability in summer conditions over the period 2013-15 offers an interesting opportunity to observe the influence of melt on summer velocity events. At White Glacier, 2012 was the second most-negative mass-balance year on record ( $-961 \mathrm{~mm}$ w.e.), 2015 the 6th most negative year (-693 mm w.e.) and 2014 the 14th most negative year ( $-407 \mathrm{~mm}$ w.e.). In contrast, 2013 had the most positive mass balance recorded since 1988 (+57 mm w.e.). For comparison, the 1968 mass balance was $-386 \mathrm{~mm}$ w.e. while the 1960 s decadal mean balance was $-108 \mathrm{~mm}$ w.e.

The cool summer temperatures in 2013 are evident in the low ablation levels recorded by the ultrasonic depth sounder at the middle profile and the correspondingly late onset of summer speed-up events in that year (Fig. 4). Compared with 2014/15, peak velocity events were of shorter duration in 2013 , as indicated by the rapid ( $<2$ days) return to velocities observed prior to the melt period, yet they resulted in the highest daily velocities observed at the three stations over the 


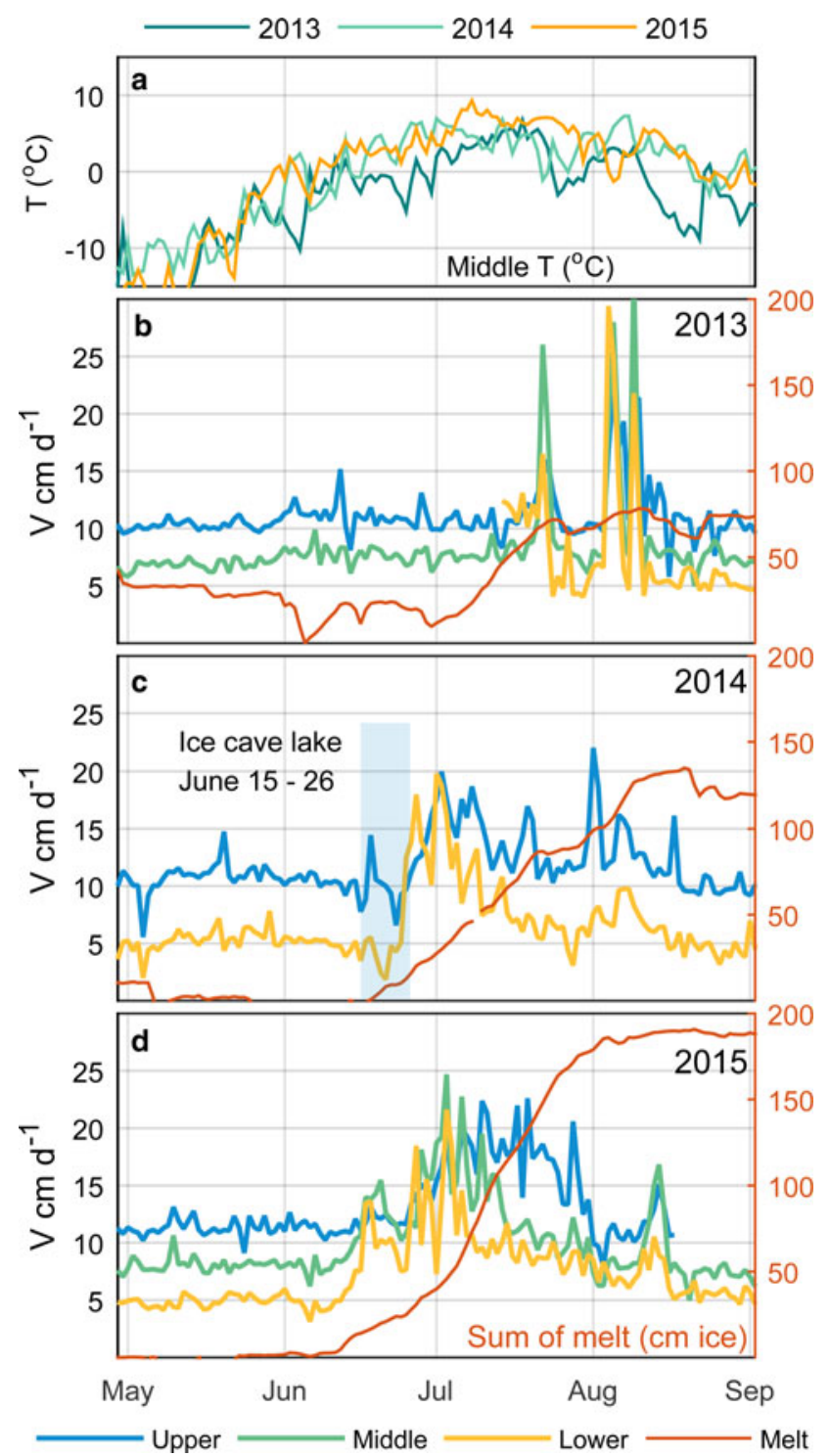

Fig. 4. (a) Climate data an automatic weather station at the middle profile for the summer of 2013-15. Velocity data derived from daily dual-frequency GPS position measurements are plotted along the left-hand $y$-axis for all profiles in (b) 2013, (c) 2014 and (d) 2015. The cumulative melt (in $\mathrm{cm}$ ) recorded at a sonic depth sounder at the middle profile is plotted in red on the right-hand axis. The light-blue region in (c) indicates the period of time spanning the formation and drainage of an ice-marginal lake $1 \mathrm{~km}$ down-glacier of lower profile. Power issues led to the failure of the middle profile GPS in 2014, explaining the absence of 2014 data from middle profile.

2013-15 record (upper: $22.3 \mathrm{~cm} \mathrm{~d}^{-1}$, middle: $32.57 \mathrm{~cm} \mathrm{~d}^{-1}$, lower: $29.4 \mathrm{~cm} \mathrm{~d}^{-1}$ ). Warmer conditions in 2014 and 2015 resulted in higher melt and the earlier onset of glacier speed-up in comparison with 2013, and in both 2014 and 2015 ice velocities did not exceed $25 \mathrm{~cm} \mathrm{~d}^{-1}$. Increases in summer velocity occur earlier in 2015 than 2014, likely in concert with the earlier onset of melt conditions in 2015. Peak velocity events appear to be longer in duration in 2014 and 2015 compared with 2013, with velocities gradually dropping near to early-May velocities over the course of several days. This is particularly true in 2015, possibly as a response to high-melt conditions in comparison with 2014. The formation (7 June-25 June) and rapid drainage (26 June) at the ice-marginal Ice Lake was recorded in
2014 using time-lapse photographs. Camera failure inhibited lake observations in 2015, but in 2016 lake formation and drainage was observed once again, suggesting that this continues to be an annual hydrological event at White Glacier.

\section{Data re-sampling}

To ensure an accurate comparison between the Iken (1974) dataset (with multi-day temporal resolution) and contemporary velocity observations (with sub-daily resolution), temporal down-sampling of the GPS data are required. Daily to multi-day velocities were calculated by differencing the 24$\mathrm{h}$ mean position between two dates, centred on local noon. Figure 5 illustrates the result of this post-processing on the duration and amplitude of peak velocity events in 1968 and 2014 when summer climate conditions were most similar (Fig. 2). Contemporary velocities calculated over a 5-day period best-preserved peak velocity events while allowing for sampling times comparable with Iken (1974). Hereafter, the Iken (1974) data are therefore only compared with down-sampled GPS velocities calculated over 5-day intervals.

\section{ANALYSIS AND DISCUSSION}

\section{Onset and duration of summer temperatures and velocities}

Müller and Iken (1973) define the summer period as those days for which the 5-day mean temperature exceeds $0^{\circ} \mathrm{C}$ $\left(s_{t}\right)$. It is also possible to define the summer period by the span of time for which the glacier exceeds a given background velocity (e.g. Sundal and others, 2011), and in this study references to 'background velocity' are taken as the minimum observed velocity of the winter season $\left(v_{m w}\right)$ preceding a given $s_{\mathrm{t}}$. Here, $s_{\mathrm{v}}$ indicates the span of days that glacier speeds are $>10 \%$ above the background velocity. Values of $s_{\mathrm{t}}$ and $s_{\mathrm{v}}$ are presented in Table 3, as well as the start and end date based on climate (for $s_{\mathrm{t}}$ ) and velocity (for $s_{\mathrm{v}}$ ). Comparing the starting dates of the two methods it is evident that in all cases the onset of summer velocities, defined as being $>10 \%$ of the minimum winter velocity, always follows the onset of $s_{\mathrm{t}}$. The situation is more variable for the end of the summer; in some years surface velocities decrease before the end of $s_{\mathrm{t}}$, whereas for other years highvelocities persist beyond $s_{\mathrm{t}}$. It is likely that this variability is associated with the ability of the subglacial hydrological system to either: (1) maintain a distributed system that supports high basal water pressures, or (2) efficiently route water from the glacier bed.

There is evidence that in 2013, when temperatures and melt were the lowest observed, limited water input into the system resulted in an inefficient subglacial drainage system that allowed high basal water pressures and peak velocities to persist 9 days after the end of the melt period at the upper station, for 44 days at the middle station and for 9 days at the lower station (Fig. 4). For 2014 and 2015 in which temperatures and melt were greater, peak velocities were halted before the end of the melt season, potentially due to an efficient subglacial hydrological system that would have allowed low subglacial water pressures (Fig. 4). However, this was not observed at the lower station where high-velocities persisted 14 days after the end of the melt period in 2014 and 19 days in 2015. The 
Table 2. Summary of mean and maximum summer velocities, both absolute and relative to annual velocities, over the duration of the temperature-defined summer period for 1968 and 2013-15 where: $s_{\mathrm{t}}=$ the summer period defined by the span of 5-day mean temperatures $>0{ }^{\circ} \mathrm{C}$, $a=$ ablation based on the interpolated ablation at the profile elevation using the mass balance gradient, $v_{a}=$ annual surface velocity (as reported in Müller and Iken (1973) and Thomson and Copland (2017)), $v_{\mathrm{s}}=$ average summer velocity calculated from the total displacement $\left(d_{\mathrm{s}}\right)$ over the summer period $\left(s_{\mathrm{t}}\right),\left(v_{\mathrm{s}}-v_{\mathrm{a}}\right) / v_{\mathrm{a}}=$ per cent increase of average summer velocity over annual velocity, $d_{\mathrm{s}} / d_{\mathrm{a}}=$ contribution of summer displacement to total annual displacement $\left(d_{\mathrm{a}}\right), v_{\text {peak }}=$ peak summer velocity observed (from 5-day down-sampled set), and $\left(v_{\text {peak- }}\right.$ $\left.-v_{m w}\right) / v_{m w}=$ percent increase of peak velocity over minimum velocity of previous winter $\left(v_{m w}\right)$

\begin{tabular}{|c|c|c|c|c|c|c|c|c|}
\hline & $\begin{array}{l}S_{\mathrm{t}} \\
\mathrm{d}\end{array}$ & $\begin{array}{l}\text { a } \\
\mathrm{cm} \text { w.e. }\end{array}$ & $\begin{array}{l}V_{\mathrm{a}} \\
\mathrm{cm} \mathrm{d}^{-1}\end{array}$ & $\begin{array}{l}v_{\mathrm{s}} \\
\mathrm{cm} \mathrm{d}^{-1}\end{array}$ & $\begin{array}{l}\left(v_{\mathrm{s}}-v_{\mathrm{a}}\right) / v_{\mathrm{a}} \\
\%\end{array}$ & $\begin{array}{l}d_{s} / d_{a} \\
\%\end{array}$ & $\begin{array}{l}V_{\text {peak }} \\
\mathrm{cm} \mathrm{d}^{-1}\end{array}$ & $\begin{array}{l}\left(v_{\text {peak }}-v_{m w}\right) / v_{m w} \\
\%\end{array}$ \\
\hline \multicolumn{9}{|c|}{ Upper (Moraine) Profile: $870 \mathrm{~m}$ a.s.l.; $8.5 \mathrm{~km}$ from terminus; $1.3 \mathrm{~km}$ wide; $378 \mathrm{~m}$ thick (1960 values) } \\
\hline 1968 & $44 \pm 6$ & $98 \pm 2$ & $10.43 \pm 1.0$ & $11.73 \pm 0.2$ & 12 & 15 & 13.9 & 33 \\
\hline 2013 & 38 & $2 \pm 2.6$ & - & $12.16 \pm 0.13$ & $14^{*}$ & $13^{*}$ & 17.8 & 109 \\
\hline 2014 & 54 & $73 \pm 0.5$ & $10.79 \pm 0.1$ & $13.93 \pm 0.13$ & 29 & 22 & 17.9 & 104 \\
\hline 2015 & 68 & $128 \pm 2.4$ & $10.53 \pm 0.1$ & $14.01 \pm 0.1$ & 33 & 30 & 18.6 & 115 \\
\hline \multicolumn{9}{|c|}{ Middle (Wind) Profile: $580 \mathrm{~m}$ a.s.l.; $5.7 \mathrm{~km}$ from terminus; $1.2 \mathrm{~km}$ wide; $298 \mathrm{~m}$ thick (1960 values) } \\
\hline 1968 & - & 152 & $10.53 \pm 1.05$ & - & - & - & 13.8 & 53 \\
\hline 2013 & 59 & $24 \pm 1$ & - & $10.82 \pm 0.05$ & $71^{+}$ & $33^{+}$ & 19.1 & 198 \\
\hline 2014 & 92 & $126 \pm 4$ & $6.34 \pm 0.04$ & $9.32 \pm 0.11$ & 47 & 50 & - & \\
\hline 2015 & 83 & $190 \pm 9$ & - & $11.01 \pm 0.03$ & $74^{+}$ & $51^{+}$ & 18.8 & 168 \\
\hline \multicolumn{9}{|c|}{ Lower (Anniversary) Profile: $370 \mathrm{~m}$ a.s.l.; $3.2 \mathrm{~km}$ from terminus; $1.0 \mathrm{~km}$ wide; $217 \mathrm{~m}$ thick (1960 values) } \\
\hline 1968 & $74 \pm 4$ & $201 \pm 68$ & 8.81 & $11.09 \pm 0.1$ & 26 & 32 & 25.6 & 199 \\
\hline 2013 & 55 & $46 \pm 1$ & $5.39 \pm 0.02 *$ & - & - & - & 16.4 & 246 \\
\hline 2014 & 92 & $171 \pm 6$ & $5.27 \pm 0.02$ & $7.37 \pm 0.02$ & 40 & 47 & 15.6 & 255 \\
\hline 2015 & 93 & $230 \pm 11$ & $5.52 \pm 0.02$ & $8.12 \pm 0.02$ & 47 & 50 & 14.8 & 247 \\
\hline
\end{tabular}

* Calculated using mean of 2014 and $2015 v_{a}$ values.

+ Calculated using $2014 v_{a}$ value.

potential cause for this discrepancy is uncertain but may be related to the thinner ice $(\sim 200 \mathrm{~m}$ in 2014$)$ and therefore lower overburden pressure at the lower profile, allowing the region to be more readily pressurized by volumes of water that would be unable to pressurize the system under thicker ice up-glacier.

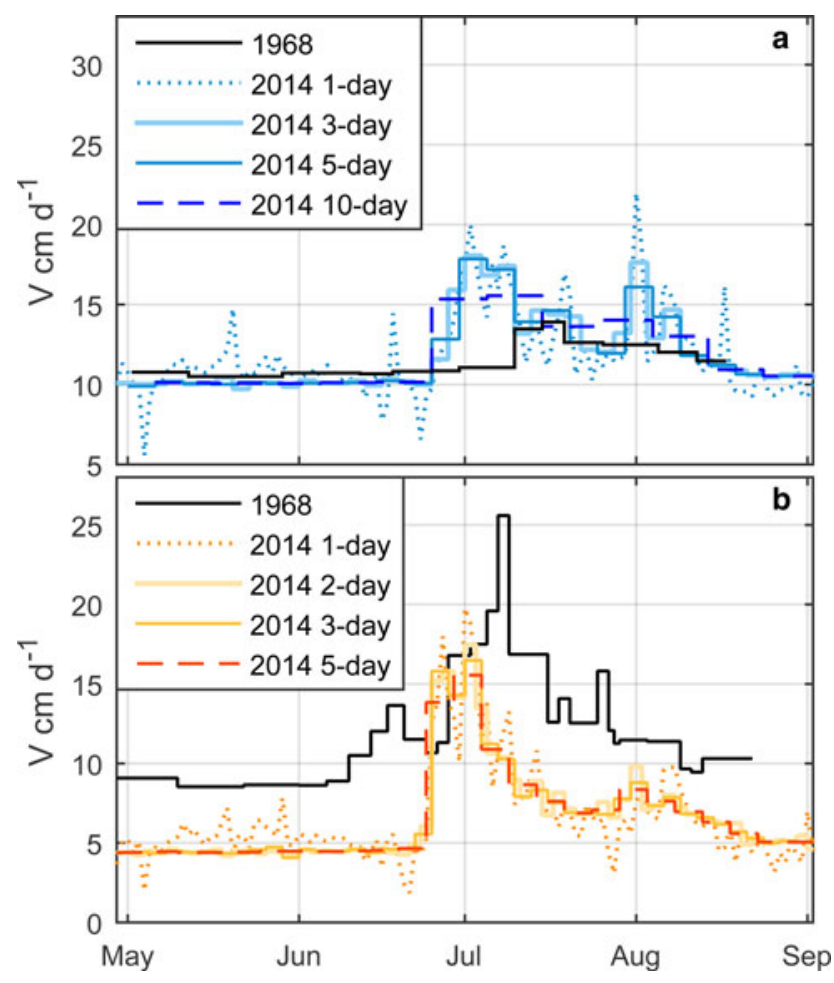

Fig. 5. Results of resampling dual-frequency GPS data at a range of temporal resolutions to allow for balanced comparison between contemporary and previous observations (Iken, 1974) at (a) the upper profile and (b) the lower profile.

\section{Contribution of total summer motion to annual displacement and flux}

Previous analysis by Iken (1974) for the upper and lower profiles, and by Thomson and Copland (2017) for all three profiles, reported the average per cent increase of summer velocities over the mean of the preceding and following winter velocities. Here the per cent increase of summer velocity over annual velocity $\left(\left(v_{\mathrm{s}}-v_{\mathrm{a}}\right) / v_{\mathrm{a}} \times 100\right)$ and the per cent contribution of summer motion to total annual displacement $\left(d_{s} / d_{a} \times 100\right)$ is considered (Table 2$)$ using the velocities $\left(v_{\mathrm{s}}\right)$ and displacements $\left(d_{\mathrm{s}}\right)$ over the entirety of the temperature-defined summer period $\left(s_{t}\right)$. Mean summer velocities $\left(v_{\mathrm{s}}\right)$ have increased at the upper profile by $1.6 \mathrm{~cm} \mathrm{~d}^{-1}$ on average since 1968, and decreased by $3.3 \mathrm{~cm} \mathrm{~d}^{-1}$ at the lower profile (Table 2). However, at both the upper and lower profiles $v_{\mathrm{s}}$ becomes proportionately greater with respect to the mean annual velocity $\left(v_{\mathrm{a}}\right)$. At the lower profile, this is in large part related to the long-term slowdown of $v_{\mathrm{a}}$ since the 1960s and the resultant increase in the relative magnitude of $v_{s}$. For the warm, high melt years of 2014 and 2015 , this relative increase in $v_{\mathrm{s}}$ has resulted in the marked increase in the contribution of $d_{\mathrm{s}}$ to the total annual displacement $\left(d_{\mathrm{a}}\right)$ (Table 2). For example, at the upper profile in 1968 $d_{\mathrm{s}}$ was responsible for $15 \%$ of $d_{\mathrm{a}}$, whereas in 2014 and 2015 this per cent contribution increased to 22 and $30 \%$, respectively. Similarly, at the lower profile in $1968 d_{\mathrm{s}}$ explained $32 \%$ of $d_{a}$, whereas in 2014 and 2015 its contribution increased to $47 \%$ and $50 \%$ of $d_{a}$, respectively. In the cool summer of 2013, in contrast, there was a slight decrease in the per cent contribution of $d_{\mathrm{s}}$ to $d_{\mathrm{a}}$ from 15 to $13 \%$ at the upper profile (Table 1). In all cases, longer summer periods $\left(s_{t}\right)$ were found to correspond with increases in the per cent contribution of $d_{\mathrm{s}}$ to $d_{\mathrm{a}}$ (Table 2), suggesting that the duration of the melt period is an important control on summer velocities and net summer displacement at White Glacier. 
Table 3. Onset and duration of summer conditions defined by the span of temperatures for which the 5 -day mean $>0{ }^{\circ} \mathrm{C}\left(s_{\mathrm{t}}\right.$, where $s_{\mathrm{t} 1}$ and $s_{\mathrm{t} 2}$ are the bounding dates), and the period of time between dates $s_{\mathrm{v} 1}$ and $s_{\mathrm{v} 2}$ for which velocities are $>10 \%$ above the minimum observed winter velocity

\begin{tabular}{|c|c|c|c|c|c|c|c|c|c|}
\hline & $\begin{array}{l}S_{\mathrm{t} 1} \\
\mathrm{~mm} / \mathrm{dd}\end{array}$ & $\begin{array}{l}S_{\mathrm{t} 2} \\
\mathrm{~mm} / \mathrm{dd}\end{array}$ & $\begin{array}{l}S_{\mathrm{t}} \\
\mathrm{d}\end{array}$ & $\begin{array}{l}S_{\mathrm{v} 1} \\
\mathrm{~mm} / \mathrm{dd}\end{array}$ & $\begin{array}{l}S_{\mathrm{v} 2} \\
\mathrm{~mm} / \mathrm{dd}\end{array}$ & $\begin{array}{l}S_{\mathrm{v}} \\
\mathrm{d}\end{array}$ & $\begin{array}{l}s_{\mathrm{v} 1}-s_{\mathrm{t} 1} \\
\mathrm{~d}\end{array}$ & $\begin{array}{l}s_{\mathrm{v} 2}-s_{\mathrm{t} 2} \\
\mathrm{~d}\end{array}$ & $\begin{array}{l}S_{v}-S_{t} \\
d\end{array}$ \\
\hline \multicolumn{10}{|c|}{ Upper (Moraine) Profile: $870 \mathrm{~m}$ a.s.l.; $8.5 \mathrm{~km}$ from terminus; $1.3 \mathrm{~km}$ wide } \\
\hline 1968 & - & - & $44 \pm 6$ & 07/10 & $08 / 12$ & $33 \pm 3$ & - & - & -11 \\
\hline 2013 & 07/04 & $08 / 11$ & 38 & $07 / 16$ & $08 / 20$ & $35 \pm 2$ & 12 & 9 & -3 \\
\hline 2014 & $06 / 19$ & $08 / 24$ & 54 & $06 / 26$ & $08 / 20$ & $55 \pm 2$ & 7 & -4 & 1 \\
\hline 2015 & 06/11 & 08/18 & 68 & $06 / 16$ & 08/15 & $55 \pm 2$ & 5 & -3 & -13 \\
\hline 1968 & - & - & - & 07/05 & $08 / 21$ & $79 \pm 3$ & - & - & - \\
\hline 2013 & $06 / 13$ & 08/11 & 59 & $07 / 11$ & $09 / 24$ & $75 \pm 2$ & 28 & 44 & 16 \\
\hline 2014 & 06/04 & $09 / 04$ & 92 & - & - & - & - & - & - \\
\hline 2015 & 06/01 & 08/23 & 83 & 06/11 & $08 / 20$ & $70 \pm 2$ & 10 & -3 & -13 \\
\hline \multicolumn{10}{|c|}{ Lower (Anniversary) Profile: $370 \mathrm{~m}$ a.s.l.; $3.2 \mathrm{~km}$ from terminus; $1.0 \mathrm{~km}$ wide } \\
\hline 1968 & $* 06 / 11$ & $* 08 / 24$ & $74 \pm 4$ & $06 / 11$ & $08 / 23$ & $73 \pm 3$ & 0 & -1 & -1 \\
\hline 2013 & 06/19 & 08/13 & 55 & - & $08 / 22$ & - & - & 9 & - \\
\hline 2015 & 06/01 & 09/02 & 93 & $06 / 13$ & $09 / 21$ & $100 \pm 2$ & 12 & 19 & 7 \\
\hline
\end{tabular}

${ }^{\prime * \prime}$ indicates dates estimated from plotted climate data in Iken (1974) and ' - ' indicate data that were not available.

If the average annual velocities from 2013 to 2015 offer a general indication of contemporary mass flux rates into the main glacier trunk it can estimated, based on annual flux calculations in Thomson and Copland (2017), that summer motion is currently responsible for delivering $2.6 \mathrm{Mt}$ of ice through the middle profile and $2.0 \mathrm{Mt}$ of ice through the lower profile each year. At the upper profile, the only site where the mean summer velocities have increased in absolute values (by 12\%, Thomson and Copland, 2017), this has resulted in an increased total annual flux through the upper profile from $1.46 \mathrm{Mta}^{-1}$ on average during the $1960 \mathrm{~s}$, to $1.99 \mathrm{Mt} \mathrm{a}^{-1}$ at present (2012-16). Considering that the ELA has risen $270 \mathrm{~m}$ above the upper profile since the 1960s, coincident with a reduction in mass in the accumulation area, this increase in mass flux at higher elevations is particularly unsustainable and will in effect act to dynamically drain the accumulation area if this velocity pattern continues into the future.

\section{Magnitude and duration of peak velocity events}

The inferred magnitude of peak velocity events (occurring over $s_{t}$ ) is sensitive to the temporal interval at which ice velocities are calculated, with larger time steps having a dampening effect on peak amplitudes. For homologous comparison of peak velocity events, the following section therefore only considers the 5-day down-sampled subset of the 2013-15 velocities introduced in the Data re-sampling section for comparison with the velocity records from Iken (1974).

The comparison of these 1968 and 2013-15 velocities at the upper, middle and lower profiles in Figure 6 illustrates two distinct spatial patterns in changes to the magnitude of peak velocities. At the upper and middle profiles, peak velocities have increased in magnitude by $\sim 5 \mathrm{~cm} \mathrm{~d}^{-1}$ in comparison with those observed during 1968. In contrast, at the lower profile peak velocities have decreased by $\sim 10 \mathrm{~cm}$ $d^{-1}$. While the lower profile exhibited the highest peak velocities during the 1960s (Müller, 1963; Iken, 1974), reaching $25.6 \mathrm{~cm} \mathrm{~d}^{-1}$ in 1968, peak events in recent years do not exceed $20 \mathrm{~cm} \mathrm{~d}^{-1}$. The location exhibiting the highest peak velocities has now shifted from the lower to the middle profile, which reached $19.1 \mathrm{~cm} \mathrm{~d}^{-1}$ in 2013. Approximately $5 \mathrm{~cm} \mathrm{~d}^{-1}$ of the decrease in peak velocities at the lower station can be explained by the overall reduction in background velocities as a result of ice thinning and declining deformation rates over the past half-century (Thomson and Copland, 2017). To understand how peak velocities have changed relative to their background velocities, the historic and contemporary records of summer velocities have been normalized to $v_{m w}$, the minimum velocity observed in their previous winter. Comparison of the relative magnitude of peak velocities indicates that peak velocities have increased from 32 to $>80 \%$ over $v_{m w}$ at the upper profile, 53 to $>160 \%$ over $v_{m w}$ at the middle profile and 200 to $>245 \%$ over $v_{m w}$ at the lower profile (Fig. 7).

The down-sampled velocity records dampen the magnitude of individual peak velocity events, thus inhibiting meaningful comparison between maximum velocities between 1968 and contemporary records. In 1968, the upper and middle profiles are characterized by a single peak that rises rapidly early in the summer period and gradually declines through the rest of the summer (Fig. 6). However, the temporal sampling at these stations also decreased to periods of $>10$ days towards the end of summer 1968, possibly leading to low magnitude peak events being missed. From 2013 to 2015 the upper and middle profiles exhibit anywhere from one to three annual peaks, but again this is highly sensitive to the temporal sampling. Rather than attempting to comment on the frequency of individual peak events, the total duration of time (i.e. total number of days) for which velocities exceed a given velocity threshold is instead considered. In a study of velocity fluctuations in a region of southwest Greenland, Sundal and others (2011) categorize ice speeds $>100 \%$ above the winter velocity as peak events. For comparison, in 1968 only the lower profile at White Glacier exhibited speed-up events $>100 \%$ above the minimum winter velocity $\left(v_{m w}\right)$, while velocities at the middle station narrowly exceeded $50 \%$ above the winter velocity and the upper station did not exceed $40 \%$ (Fig. 7). Comparison of summer velocities and $v_{m w}$ in recent years, however, shows significant increases in the relative 

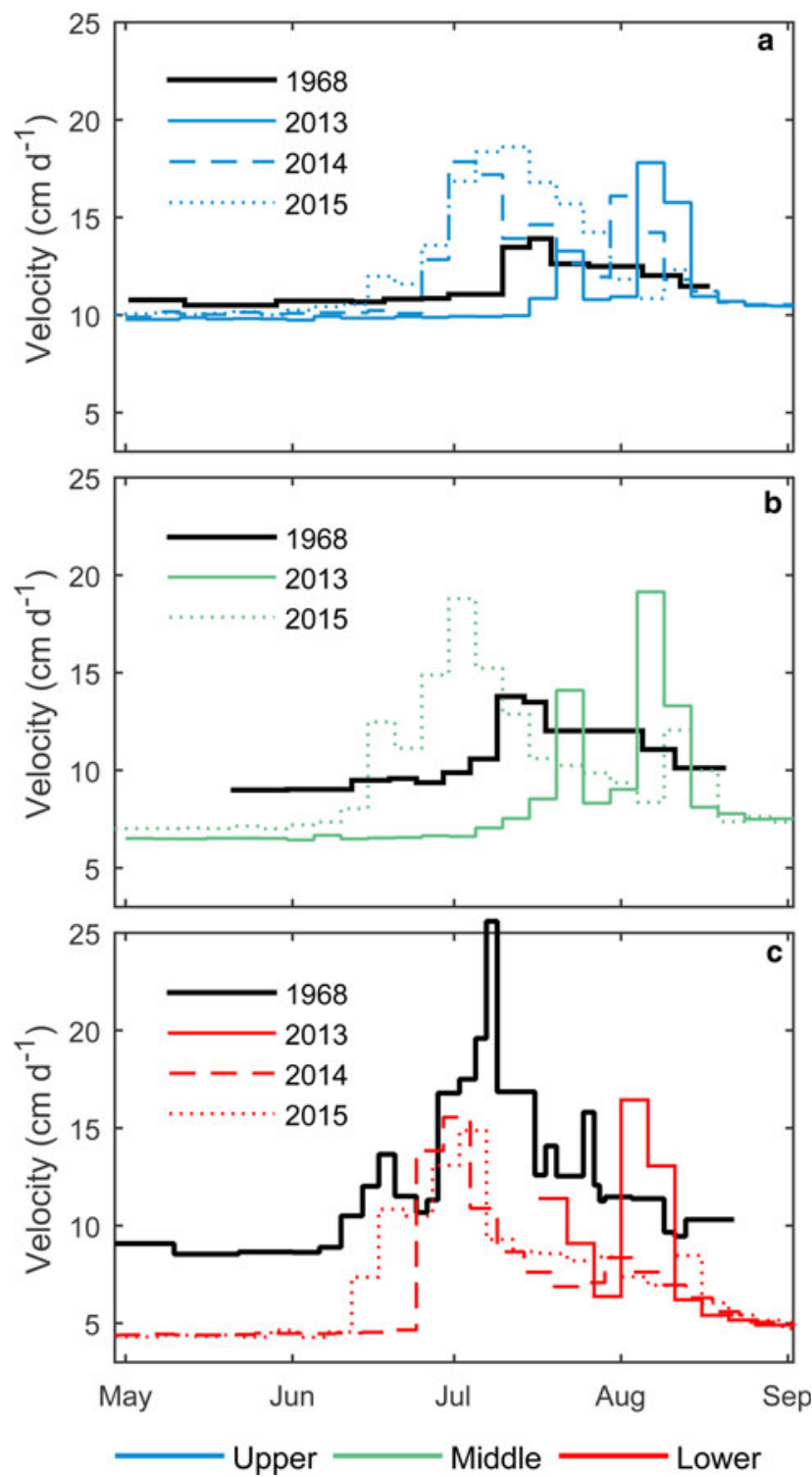

Fig. 6. Summer velocities observed between 1968 and 2013-15 at the (a) upper, (b) middle and (c) lower profiles. The 2013-15 data are down-sampled to 5-day intervals, which was the approximate temporal spacing of the 1968 observations. Power issues led to the failure of the middle profile GPS in 2014, explaining the absence of 2014 data from middle profile.

magnitude of summer speed-up events. To determine the total duration and contribution of peak velocity events to annual displacement, a series of threshold experiments were conducted in which peak events were defined as those events exceeding 25, 50, 100 and $200 \%$ above $v_{m w}$. Here, total duration is defined as the number of days in which velocities exceeded a given threshold.

The total duration of peak events $>25 \% \quad v_{m w}$ has increased at all stations since 1968, with the one exception being the lower profile in 2013 (Table 4). With increasing $\% v_{m w}$ thresholds, a spatial pattern emerges where the higher relative magnitude events occur more often at lower elevations:

- $>25 \% v_{m w}$ events occur at all profiles in all years (1968 and 2013-15)

- $>50 \% v_{m w}$ events occur at all profiles between 2013 and 2015
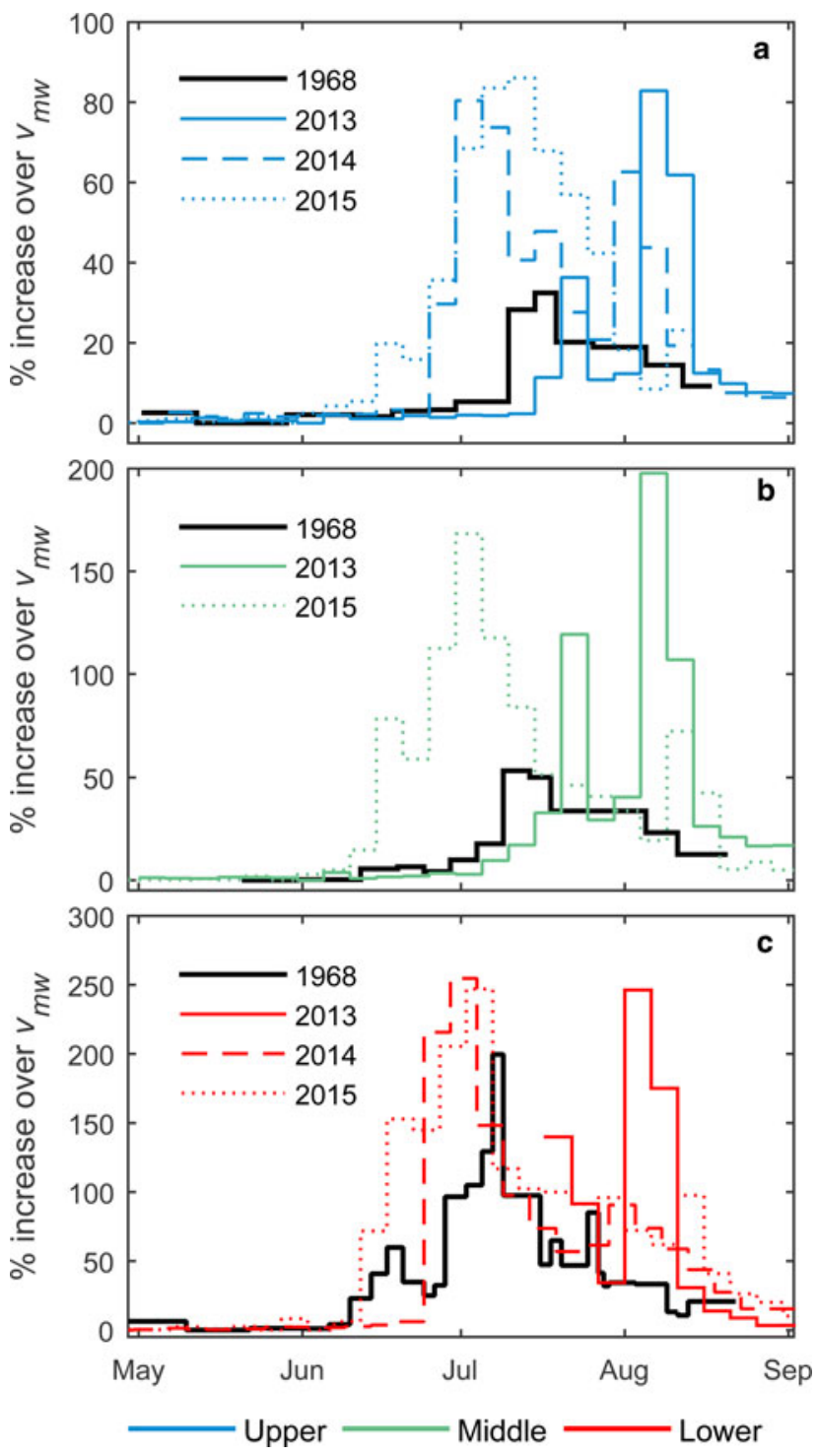

Fig. 7. Summer velocities normalized to the minimum velocity of the previous winter $\left(v_{m w}\right)$ between 1968 and 2013-15 at the (a) upper, (b) middle and (c) lower profiles. The 2013-15 data are down-sampled to 5-day intervals, the approximate temporal spacing of the 1968 observations. Power issues led to the failure of the middle profile GPS in 2014, explaining the absence of 2014 data from middle profile.

- $>100 \% v_{m w}$ events occur at the lower profile in all years including 1968, but only at the middle profile in recent years (2013-15)

- $>200 \% v_{m w}$ events occur only at the lower profile in 2013-15

Peak events at any given threshold also, in general, have a greater total duration in 2013-15 compared with 1968. This analysis indicates that despite the greatest decrease in annual velocities since the 1960s, the lower profile continues to exhibit the longest duration and highest relative magnitude (Fig. 7) of peak velocity events since the observations of Iken (1974). In concert with the pattern of increased total duration of peak velocity events in recent years, the displacement associated with peak velocity events $\left(d_{\text {peak }}\right)$ is increasing relative to annual displacement $\left(d_{\mathrm{a}}\right)$ at each station (Table 4). 
Table 4. Number of days on which summer velocities exceed a given percentage (25, 50, 100 , or $200 \%)$ of the mean annual velocity $\left(v_{\mathrm{a}}\right)$, and the corresponding percentage that displacement during those dates $\left(d_{\text {peak }}\right)$ has contributed to total annual displacement $\left(d_{\mathrm{a}}\right)$

\begin{tabular}{|c|c|c|c|c|c|c|c|c|}
\hline \multirow[t]{2}{*}{$\%$ above $v_{a}$} & \multicolumn{2}{|l|}{$25 \%$} & \multicolumn{2}{|l|}{$50 \%$} & \multicolumn{2}{|l|}{$100 \%$} & \multicolumn{2}{|l|}{$200 \%$} \\
\hline & \# days & $\% d_{a}$ & \# days & $\% d_{a}$ & \# days & $\% d_{a}$ & \# days & $\% d_{a}$ \\
\hline \multicolumn{9}{|c|}{ Upper (Moraine) Profile: $870 \mathrm{~m}$ a.s.l.; $8.5 \mathrm{~km}$ from terminus; $1.3 \mathrm{~km}$ wide } \\
\hline 1968 & 9 & 3 & 0 & 0 & 0 & 0 & 0 & 0 \\
\hline 2013 & 15 & 6 & 10 & 4 & 0 & 0 & 0 & 0 \\
\hline 2014 & 40 & 15 & 15 & 7 & 0 & 0 & 0 & 0 \\
\hline 2015 & 35 & 15 & 25 & 11 & 0 & 0 & 0 & 0 \\
\hline \multicolumn{9}{|c|}{ Middle (Wind) Profile: $580 \mathrm{~m}$ a.s.l.; $5.7 \mathrm{~km}$ from terminus; $1.2 \mathrm{~km}$ wide } \\
\hline 1968 & 27 & 9 & 9 & 3 & 0 & 0 & 0 & 0 \\
\hline 2013 & 35 & 15 & 15 & 9 & 15 & 8.7 & 0 & 0 \\
\hline 2014 & - & - & - & - & - & - & - & - \\
\hline 2015 & 60 & 28 & 40 & 20 & 15 & 9.2 & 0 & 0 \\
\hline \multicolumn{9}{|c|}{ Lower (Anniversary) Profile: 370 m a.s.l.; $3.2 \mathrm{~km}$ from terminus; $1.0 \mathrm{~km}$ wide } \\
\hline 1968 & 54 & 24 & 25 & 14 & 7 & 4.5 & 0 & 0 \\
\hline 2013 & 30 & 16 & 20 & 13 & 15 & 10.4 & 5 & 4.2 \\
\hline 2014 & 65 & 28 & 50 & 24 & 15 & 10.2 & 10 & 7.5 \\
\hline 2015 & 75 & 34 & 65 & 31 & 30 & 17 & 10 & 7.1 \\
\hline
\end{tabular}

For 2013-2015, \# days are multiples of 5 as a result of the temporal resampling post-processing.

\section{Speed-up associated with lake formation and drainage}

Records of the formation and drainage of the ice-dammed lce cave Lake along the western margin of White Glacier are available for 1968 and 2014. In 1968, the lake formed over a period of 5 days (30 May to 4 June) and slowly drained into an ice cave over a period of 17 days until 21 June when the lake was fully emptied. The initiation of spring speed-up preceded the lake drainage; velocities were observed to exceed $v_{m w}$ by $23 \%$ on 11 June, by $41 \%$ on 15 June and reached a maximum of $60 \%\left(13.65 \mathrm{~cm} \mathrm{~d}^{-1}\right)$ on 18 June, after which they dropped to $34 \%$ above $v_{m w}$ on 21 June, the next date of observation. The timing of these observations could be explained by a constant supply of water to the subglacial system over the 17 days that the lake drained. This would support the steady increase in velocity at the lower profile until the reservoir was depleted on 21 June, leading to a drop in the subglacial water pressure.

The formation of a lake at the same location in 2014 began on 12 June, and water levels steadily rose until 15 June when the lake reached maximum capacity. Small fluctuations in the lake level $(<1 \mathrm{~m})$ were observed over the following 10 days until 25 June. On 26 June the lake level had dropped to an estimated $15 \%$ of the 25 June level, and the lake was fully emptied by 30 June. Unlike in 1968, ice velocities at the lower profile in 2014 did not show an increase over $v_{m w}$ prior to the formation of the marginal lake and remained relatively constant until 26 June when the majority of the lake drained into the ice cave, upon which ice velocities rose from $v_{m w}$ to $215 \%$ above $v_{m w}$ over the course of 1 day.

The dynamic behaviour occurring in concert with the lake formation and drainage differs between the 2 years; whereas ice velocities at the lower profile increased incrementally from $\sim v_{m w}$ to $>60 \%$ above $v_{m w}$ over the period of one week in 1968, the 2014 speed-up event exceeded $>200 \%$ above $v_{m w}$ and occurred near-simultaneously with the rapid lake drainage over the period of 1-2 days. The discrepancy in dynamic behaviour is potentially associated with the ability of the ice cave channel to connect with the broader subglacial network through en- or sub-glacial melt and subsequent channel formation, thus allowing a large volume of water to enter the subglacial network, increase water pressures and reduce basal friction. However, there is also the possibility that a dynamic event unrelated to the lake drainage caused speed-up of the glacier on 26 June 2014, which could have induced basal ice fracturing in the subglacial environment and provided a new route through which the lake could drain. The daily photographs from 2014 do not provide the temporal resolution to distinguish what came first, the lake drainage or the speed-up, but the new instrumentation is in place to investigate this site in the future.

\section{CONCLUSIONS}

Several changes have occurred to the magnitude and duration of peak velocity events (observed over 5-day periods) at White Glacier since the 1960s, which have altered the overall contribution of summer motion to annual motion:

(1) The absolute magnitude of peak velocities have increased by $\sim 5 \mathrm{~cm} \mathrm{~d}^{-1}$ at the upper and middle profiles (from 13.5 to $\sim 18 \mathrm{~cm} \mathrm{~d}^{-1}$ and 13.7 to $\sim 19 \mathrm{~cm} \mathrm{~d}^{-1}$, respectively) since 1968, while peak velocities have decreased by $\sim 10 \mathrm{~cm} \mathrm{~d}^{-1}$ at the lower profile (from 25.6 to $\sim 16 \mathrm{~cm} \mathrm{~d}^{-1}$ );

(2) The relative magnitude of peak velocities (normalized by the minimum velocity observed in the previous winter) has increased significantly at all profiles, with the greatest increase occurring at the lower profile. At this location peak velocities now exceed previous winter minimum velocities by $>250 \%$ (Fig. 7), compared with peaks of $\sim 200 \%$ in 1968;

(3) As a result of the increasing relative magnitude and number of days exhibiting peak velocities, the contribution of summer motion to annual displacement has increased from $15 \%$ to up to $30 \%$ at the upper profile, and from $32 \%$ to up to $50 \%$ at the middle and lower profiles (Table 2).

In contrast, features of summer dynamics that remain unchanged at White Glacier since observations in the 1960s by Iken (1974) include continuation of the lower profile exhibiting the largest range of velocity fluctuations, both absolute and relative to mean annual velocities, and 
the formation and drainage of an ice-marginal lake in conjunction with the first summer speed-up event. The increased contribution of summer motion to annual displacement likely explains, in part, why observed mass flux through the crosssectional area of all three profiles is significantly out of balance with modelled balance fluxes derived from the 55year mass-balance record (Thomson and Copland, 2017).

The peak velocity events described here are expected to be primarily associated with basal motion, likely in the form of basal sliding, in response to high basal water pressures during the summer melt period. With the continuation of negative surface mass-balance conditions, ice thinning and corresponding reductions in ice deformation rates, it appears likely that summer dynamics driven by basal motion will play an increased role in total glacier motion in the future. However, as ice deformation rates decline to stagnation as the ice thins there is an increased likelihood of subglacial channels persisting through the winter, which could efficiently route water from the glacier bed at the onset of melt the following summer and result in lower basal sliding. Evidence of this latter-phase of subglacial hydrological evolution may have already been observed at White Glacier where, in 2010, a large $\left(\sim 0.5 \mathrm{~km}^{2}\right)$ collapse feature formed near the terminus, exposing well developed, multi-year subglacial and englacial channels. The dominance of cold $\left(<-10^{\circ} \mathrm{C}\right)$ ice in Canadian high-Arctic glaciers, resulting in slower creep and channel closure rates, will make these ice masses particularly prone to early stagnation and collapse under future negative mass-balance conditions.

\section{ACKNOWLEDGEMENTS}

This research was supported by the Natural Sciences and Engineering Research Council of Canada, Canada Foundation for Innovation, Ontario Research Fund, ArcticNet, University of Ottawa, the W. Garfield Weston Foundation, and the Northern Scientific Training Program. We acknowledge the continued support of the Canadian Polar Continental Shelf Program for providing field logistics at Expedition Fiord, and Wayne Pollard who manages the McGill Arctic Research Station where this study was based. We sincerely thank Miles Ecclestone and the many others who assisted in carrying out fieldwork at White Glacier. The comments and suggestions provided by the reviewers and Annals of Glaciology editorial team are greatly appreciated.

\section{REFERENCES}

Adams WP (2007) Trent, McGill and the North: a story of Canada's growth as a sovereign polar nation. Cover to Cover Publication Services, Peterborough, Ontario

Anderson B and 6 others (2014) Annual to daily ice velocity and water pressure variations on Ka Roimata o Hine Hukatere (Franz Josef Glacier), New Zealand. Arct. Antarct. Alpine Res., 46(4), 919-932

Bartholomaus TC, Anderson RS and Anderson SP (2008) Response of glacier basal motion to transient water storage. Nature, $\mathbf{1}$, 33-37

Battle WRB (1951) Glacier movement in north-east Greenland, 1949: with a note on some subglacial observations. J. Glaciol., 1(10), 4
Bingham RG, Nienow PW and Sharp M (2003) Intra-annual and intra-seasonal flow dynamics of a high Arctic polythermal valley glacier. Ann. Glaciol., 37(1), 181-188

Bingham RG, Nienow PW, Sharp M and Copland L (2006) Hydrology and dynamics of a polythermal (mostly cold) high Arctic glacier. Earth Surf. Process. Landf., 31, 17

Blatter H (1987) On the thermal regime of an Arctic valley glacier: a study of White Glacier, Axel Heiberg Island, N.W.T., Canada. J. Glaciol., 33(114), 200-211

Cogley JG, Adams WP, Ecclestone MA, Jung-Rothenhäusler F and Ommanney CS (1996) Mass balance of White Glacier, Axel Heiberg Island, N.W.T., 1960-1991. J. Glaciol., 42(142), 548-563

Copland L, Sharp M and Nienow PW (2003) Links between shortterm velocity variations and the subglacial hydrology of a predominantly cold polythermal glacier. J. Glaciol., 49(166), 337-348

Cuffey KM and Paterson WSB (2010) The physics of glaciers, 4th edn. Elsevier, Amsterdam

Friese-Greene TW and Pert GJ (1965) Velocity fluctuations of the Bersaekerbrae, East Greenland. J. Glaciol., 5(41), 9

Glen JW (1955) The creep of polycrystalline ice. Proc. R. Soc. Lond. A: Math. Phys. Eng. Sci., 228(1175), 519-538

Hambrey MJ and 7 others (2005) Structure and changing dynamics of a polythermal valley glacier on a centennial timescale: Midre Lovenbreen, Svalbard. J. Geophys. Res., 110, 19

Haumann D and Honegger D (1964) White Glacier, Axel Heiberg Island, Canadian Arctic Archipelago. Ottawa, Canada

Heid T and Kääb A (2012) Repeat optical satellite images reveal widespread and long term decrease in land-terminating glacier speeds. Cryosphere, 6, 467-479

Iken A (1974) Velocity fluctuations of an Arctic valley glacier, A study of the White Glacier, Axel Heiberg Island, Canadian Arctic Archipelago. Axel Heiberg Island Research Reports, Glaciology, Montreal, Canada, No. 5, 123 pp.

Maag HU (1969) Ice-dammed lakes and marginal glacial drainage on Axel Heiberg Island, Canadian Arctic Archipelalgo. Axel Heiberg Island Research Reports, Montreal, Canada 47 pp.

Müller F (1963) Preliminary report 1961-1962. McGill University, Montreal, Quebec, Canada

Müller F and Iken A (1973) Velocity fluctuations and water regime of Arctic valley glaciers. In Paper Presented at the Symposium on the Hydrology of Glaciers, 7-13 September 1969, Cambridge

Nolan M, Motkya R, Echelmeyer K and Trabant D (1995) Ice-thickness measurements of Taku Glacier, Alaska, U.S.A., and their relevance to its recent behavior. J. Glaciol., 41(139), 541-553

Schaffer N, Copland L and Zdanowicz C (2017) Ice velocity changes on Penny Ice Cap, Baffin Island, since the 1950s. J. Glaciol. 63(240), 716-730 (doi: 10.1017/jog.2017.40)

Sundal AV and 5 others (2011) Melt-induced speed-up of Greenland ice sheet offset by efficient subglacial drainage. Nature, $\mathbf{4 6 9}(4)$, 521-524

Thomson L and Copland L (2016) White Glacier 2014, Axel Heiberg Island, Nunavut: mapped using structure from motion methods. J. Maps, 12(5), 1063-1071

Thomson L and Copland L (2017) Multi-decadal reduction in glacier velocities and mechanisms driving deceleration at polythermal White Glacier, Arctic Canada. J. Glaciol., 63(239), 450-463

Thomson L, Zemp M, Copland L, Cogley G and Ecclestone M (2017) Comparison of geodetic and glaciological mass budgets for White Glacier, Axel Heiberg Island, Canada. J. Glaciol., 63 (237), 55-66 (doi: 10.1017/jog.2016.112)

WGMS (2015) Global glacier change bulletin no. 1 (2012-2013). World Glacier Monitoring Service, Zurich, Switzerland 